\title{
Sport jako element soft power Kataru
}

\begin{abstract}
Streszczenie: Do niedawna Katar pozostawał państwem mało rozpoznawalnym na świecie. W wyniku przemyślanej, wieloletniej strategii budowy marki, powiązanej ściśle z polityką zagraniczną i bezpieczeństwa, Katar stał się nie tylko rozpoznawalnym w skali globu państwem, ale za sprawą nieproporcjonalnej do swego geograficznego rozmiaru aktywności międzynarodowej godną zaufania marką, znaną i szanowaną na najważniejszych salonach politycznych i w kręgach dużego biznesu. Celem głównym niniejszego artykułu jest zanalizowanie jednego z elementów strategii budowania międzynarodowej marki Kataru, jaką jest wykorzystanie sportu w celach politycznych oraz odpowiedzenia na pytanie, na ile sport w niniejszym przypadku pozwala zrealizować zakładane cele strategiczne. By to zrobić, w pracy zanalizowano wymiar wewnętrzny i zewnętrzny (międzynarodowy) polityki sportowej Kataru.
\end{abstract}

Słowa kluczowe: polityka zagraniczna Kataru, soft power, sport, budowa marki

\section{Wstęp}

zterdzieści lat temu Katar był w oczach Francuzów niczym więcej jak tylko pu" stynią z niewielką ilością ropy” - stwierdził kilka lat temu na łamach „Le Point” francuski dyplomata - ,pięć lat temu większość Francuzów nawet nie wiedziała gdzie leży Katar" (Ayoub, 2012). Wydaje się, że taką konstatację odnieść można było nie tylko do Francuzów, ale do większości mieszkańców Zachodu, którzy do niedawna zapewne byliby w stanie wymienić tylko takie państwa z Zatoki Perskiej jak Iran, Irak, Arabia Saudyjska czy też Kuwejt. Katar był państwem praktycznie nieznanym poza kręgiem badaczy świata arabskiego.

W ostatnich latach sytuacja uległa diametralnej zmianie. Za sprawą emira Szajcha Hamada Ibn Chalify Al Saniego, sprawującego nieprzerwanie władzę w latach 1995-2013 (w wyniku bezkrwawego przewrotu i obalenia swego ojca) ${ }^{1}$, Katar stał się nie tylko rozpoznawalnym w skali globu państwem, ale za sprawą nieproporcjonalnej do swego geograficznego rozmiaru aktywności międzynarodowej godną zaufania marką, znaną na najważniejszych salonach politycznych i w kręgach dużego biznesu.

\section{Geneza soft power Kataru}

Pierwszym elementem budowy swojego wizerunku, połączonej z wkraczaniem na międzynarodowe salony, stała się narodowa linia lotnicza Qatar Airways, powołana w 1994 roku. W krótkim czasie zyskała ona reputację jednej z najlepszych na świecie

${ }^{1}$ Emir 25 czerwca 2013 roku oddał dobrowolnie władzę. Nowym przywódcą został Szajch Tamim Ibn Chalifa Al Sani. 
- w rankingu brytyjskiej firmy konsultingowej Skytrax otrzymała aż pięć gwiazdek. Drugim krokiem była Al Dżazira, powołana w listopadzie 1996 roku katarska telewizja, formalnie niezależna, ale będąca pod kontrola, a przynajmniej wyraźnym wpływem, monarchy. Stacja telewizja stała się z jednej strony instrumentem politycznym w rękach władcy, a z drugiej najbardziej rozpoznawalnym symbolem tego państwa. Sukces Al Dżaziry w budowaniu wizerunku Kataru zachęcił emira do kontynuacji takiej polityki.

Rozpoznawalność w kolejnej fazie zwiększono za sprawą organizowania wielkich imprez o wymiarze tak regionalnym, jak i globalnym, których wcześniej Katar raczej nie gościł². Do tych najważniejszych zaliczyć można szczyt klimatyczny ONZ i Światowej Organizacji Handlu, liczne wydarzenia kulturalne - w tym Qatar Cultural Festival oraz Tribeca Film Festival - a także sportowe: turnieje tenisowe ATP, WTA, ExxonMobil Open, golfowe Qatar Masters, czy coroczne wyścigi Moto Grand Prix. W 2005 roku Katar z powodzeniem zorganizował III Igrzyska Zachodnio-Azjatyckie, a rok później XV Igrzyska Azjatyckie, które według oficjalnego stanowiska miały stanowić dowód przywiązania do „uniwersalnych wartości demokracji, solidarności i praw człowieka" (Amara, 2013, s. 103). W praktyce jednak stanowiły przede wszystkim sukces marketingowy, dający - jak stwierdził D. Whitelegg - „niezrównaną możliwość ściagnięcia uwagi dużej liczby osób" (Whitelegg, 2000, s. 802). Podobny mechanizm dotyczy organizacji kolejnych dużych imprez sportowych, między innymi halowych mistrzostw Azji w lekkoatletyce (2008), klubowych mistrzostw świata w piłce siatkowej mężczyzn (2009, 2010, 2011, 2012), halowych mistrzostw świata w lekkoatletyce (2010), Pucharu Azji w piłce nożnej (2011) oraz igrzysk panarabskich (2011). W 2014 roku goszczono 12. mistrzostwa świata w pływaniu na krótkim basenie, a rok później mistrzostwa świata w piłce ręcznej mężczyzn. Promocja i budowa międzynarodowej pozycji za pośrednictwem sportu była prowadzona równocześnie obok „dyplomacji dolarowej”, dzięki której Katar zyskał również międzynarodową renomę jako skuteczna i hojna instytucja mediacyjna. Katar wziął bowiem udział w negocjacjach arabsko-izraelskich, pomógł osiagnąć porozumienie w Libanie, zaangażował się w libijski kryzys wokół bułgarskich pielęgniarek. Przeprowadził mediacje w konflikcie w Jemenie i na Filipinach. Później aktywny był w kryzysie syryjskim.

Utworzono Międzynarodowe Centrum Bezpieczeństwa Sportu (International Centre of Sport Security) oraz laboratorium antydopingowe, a także stworzono pod skrzydłami Aspire Zone Foundation formułę DOHA GOALS (Gathering Of All Leaders in Sports), która stanowi coroczne spotkanie na szczycie najważniejszych ludzi ze świata sportu. Wszystkie te działania nie są przypadkowe, lecz składają się na bardzo przemyślany, długofalowy i wieloetapowy plan strategiczny, którego celem jest już nie tylko ,umieszczenie Kataru na mapie świata", jak ujął to kilka lat temu John E. Peterson (Peterson, 2009, s. 51), ale obecnie przede wszystkim wzmocnienie pozycji tego państwa w systemie międzynarodowym i spotęgowanie zdolności do oddziaływania na innych aktorów zgodnie ze swoją wolą. Innymi słowy, Katar chce stać się państwem dużo ważniejszym i silniejszym niż był w przeszłości.

${ }^{2}$ W 1988 roku Katar gościł Puchar Azji w piłce nożnej, w 1995 roku piłkarskie mistrzostwa świata w piłce nożnej do lat 20, a w 1999 roku młodzieżowe mistrzostwa świata w piłce ręcznej. Chronologicznie pierwszą zorganizowaną imprezą był Puchar Narodów Zatoki w piłce nożnej w 1976 roku. 
Oczywiste jest, iż ze względu na negatywne oddziaływanie stałych czynników o charakterze obiektywnym, to jest niewielkiego rozmiaru geograficznego oraz ograniczonej populacji, Katar nigdy nie stanie się pełnowymiarową potęgą o wymiarze międzynarodowym (globalnym), szczególnie w aspekcie militarnym. Mając świadomość swej słabości w zakresie hard power emir rozwinął inne elementy potegi państwa, które - odwołując się do Josepha S. Nye'a, określić można jako soft power. Za ich sprawą ,inni czynią to, co chcemy” (,getting others to do what you want”), pojawia się możliwość skutecznego kształtowania decyzji, preferencji pozostałych uczestników systemu międzynarodowego bez posuwania się do użycia siły lub groźby jej zastosowania, lecz na zasadzie przyciagania, przekonywania, a nawet - jak to ma miejsce w przypadku ,dyplomacji dolarowej" - czasem przekupywania (Nye, 2004, s. 6). W odczuciu Johna E. Petersona tego rodzaju działania są zgodne ze ,strategia przetrwania”, wymagająca, aby małe państwo próbowało „wykorzystać wyjątkową niszę, która umożliwia mu zapewnianie korzystnych usług sąsiadom, regionowi czy światu” (Peterson, 2009, s. 61). Co więcej, poprzez aktywność na tak dużą skalę - to jest organizowanie międzynarodowych imprez sportowych - Katar buduje swój wizerunek jako partnera wiarygodnego, który - jak stwierdził jeden z katarskich decydentów - jest zdolny podołać wielkiej odpowiedzialności” (Brannagan, Gulianotti, 2014, s. 161).

W przypadku Kataru użycie soft power w polityce zagranicznej jest konieczne, bowiem nie ma innych efektywnych metod realizowania swych interesów, a także możliwe, bowiem państwo to posiada zasoby pozwalające prowadzić taką właśnie politykę. W przypadku Kataru źródłem bogactwa, czy też pozostając wiernym terminologii z zakresu teorii strategii, środkiem (means), są gigantyczne pokłady surowców energetycznych, szczególnie gazu ziemnego (trzecie zasoby na świecie). W 2012 roku przychody z gazu ziemnego stanowiły aż 50 procent PKB i 70 procent wszystkich przychodów państwa (Qatar, 2013).

To właśnie te niemal nieograniczone zasoby sprawiaja, że aktywność międzynarodowa może być nieproporcjonalnie duża w porównaniu z rozmiarem Kataru. W ten sposób Katar, mimo swych ograniczeń (chociażby geograficznych), staje się równie znany jak Tajwan czy Szwajcaria, a więc państwa niewielkie, ale niezwykle prężne politycznie i gospodarczo. Rośnie także jego międzynarodowa legitymacja. Taka polityka przynosi korzyści nie tylko polityczne i gospodarcze (zwiększenie prestiżu państwa, skuteczności działań dyplomatycznych, zwiększenie zainteresowania firm zewnętrznych, napływ inwestycji zagranicznych), ale również militarne. Pozwala bowiem zwiększyć zainteresowanie ze strony mocarstw, które gotowe są bronić Kataru w sytuacji kryzysowej.

\section{Znaczenie sportu w polityce państwa w świetle dokumentów rządowych}

Jednym z elementów mogącym wspomagać soft power, jest sport, który w Katarze rozwija się dynamicznie. Jak słusznie zauważyli Russell Hoye, Matthew Nicholson oraz Barrie Houlihan w swej pracy Sport and Policy, sport nie jest już tylko wyłącznie dziedziną prywatnej aktywności, czy też przedmiotem zainteresowania biznesmenów (z powodów finansowych), lecz staje się istotnym elementem polityki państwa. Coraz częściej państwa formułują i realizują coś, co autorzy nazywają ,polityką sportową” (sport 
policy), a co nastawione jest na realizowanie określonych celów nadrzędnej polityki zagranicznej (Hoye, Nicholson, Houlihan, 2010, s. 1). W tym przypadku jest to wspieranie soft power Kataru. Widać to wyraźnie, przykładowo, w odniesieniu do Polski, która współorganizowała mistrzostwa Europy w piłce nożnej (2012), czy też Rosji, dla której goszczenie zimowych igrzysk olimpijskich (2014) oraz mistrzostw świata w piłce nożnej (2018), dla których wymiar sportowy był mniej istotny od zakładanych korzyści polityczno-prestiżowych.

Oficjalne podejście do roli sportu w polityce państwa odnaleźć można w opublikowanych w ostatnich latach dokumentach o charakterze strategicznym. Koncentrują się one w odniesieniu do sportu w znacznym stopniu na celach wewnętrznych. O tym, że sport jest istotną dla państwa formą aktywności świadczy „,Qatar National Vision 2030”, gdzie sport zajmuje cały rozdział (,,Sports as inspiration for an active and healthy society"), a także stanowi integralną część występującą w czterech filarach uznawanych za podstawowe dla pomyślnego rozwoju Kataru w nadchodzących latach: rozwoju jednostki, społeczeństwa, gospodarki oraz środowiska naturalnego (human, social, economic, environmental developoment). Udział sportu w tych elementach przedstawiono w tabeli 1.

Tabela 1

Miejsce sportu w strategii rozwoju Kataru (Qatar National Vision 2030)

\begin{tabular}{|c|c|c|c|}
\hline \multicolumn{4}{|c|}{ „Qatar National Vision 2030” } \\
\hline \multicolumn{4}{|c|}{ „National Development Strategy" } \\
\hline \multicolumn{4}{|c|}{ Strategie sektorowe - sport } \\
\hline Rozwój jednostki & Rozwój społeczny & Rozwój gospodarczy & Rozwój środowiska \\
\hline $\begin{array}{l}\text { Rozwój wszystkich oby- } \\
\text { wateli prowadzi do stwo- } \\
\text { rzenia prosperującego spo- } \\
\text { feczeństwa: } \\
\text { - zdrowe społeczeństwo } \\
\text { - fizycznie i psychicz- } \\
\text { nie, } \\
\text { - udział w sporcie i roz- } \\
\text { wój umiejętności, } \\
\text { - edukacja i trening }\end{array}$ & $\begin{array}{l}\text { Stworzenie sprawiedliwe- } \\
\text { go i opiekuńczego spo- } \\
\text { łeczeństwa z wysokimi } \\
\text { standardami moralnymi, } \\
\text { aktywne w światowym } \\
\text { rozwoju: } \\
\text { - jedność rodziny, zwięk- } \\
\text { szenie samodzielności } \\
\text { kobiet, } \\
\text { - rozwój wspólnot, bez- } \\
\text { piecznego i stabilnego } \\
\text { społeczeństwa, } \\
\text { - zwiększona rola regio- } \\
\text { nalna i międzynarodo- } \\
\text { wa }\end{array}$ & $\begin{array}{l}\text { Stworzenie konkurencyj- } \\
\text { nej i zdywersyfikowanej } \\
\text { gospodarki celem zapew- } \\
\text { nienia pomyślności obec- } \\
\text { nym i przyszłym pokole- } \\
\text { niom: } \\
\text { - wydarzenia sportowe } \\
\text { oraz usługi związane ze } \\
\text { sportem, } \\
\text { - zwiększona produkcyj- } \\
\text { ność dzięki zdrowemu } \\
\text { społeczeństwu }\end{array}$ & $\begin{array}{l}\text { Zapewnienie harmonii } \\
\text { między wzrostem gospo- } \\
\text { darczym, rozwojem spo- } \\
\text { łecznym i środowiskiem } \\
\text { naturalnym } \\
\text { - przyjazna środowisku } \\
\text { infrastruktura sportowa, } \\
\text { - wykorzystywanie sportu } \\
\text { do promowania wiedzy } \\
\text { na temat środowiska na- } \\
\text { turalnego }\end{array}$ \\
\hline
\end{tabular}

Źródlo: Sports Sector Strategy (2011-2016), Qatar Olympic Committee, Doha 2011, s. 11.

Szczegóły odnaleźć można w dokumencie „, Sport Sector Strategy 2011-2016”, który stanowi jedną z czternastu strategii składających się na strategię państwową. W tejże publikacji Katar wydzielił sześć priorytetowych obszarów działania. Pierwszy z nich dotyczy infrastruktury sportowej (Sport \& Leisure Facilities): rozbudowy obecnie istniejacej i stworzenia nowej. Drugi element zakłada promocję (Promotion and Publicity), choćby poprzez uczynienie z Kataru rozpoznawalnej marki jako miejsca dla turystów. Trzeci koncentruje się na edukacyjnej i społecznej roli sportu (Sports Education \& Par- 
ticipation): zwiększeniu udziału kobiet oraz niepełnosprawnych, podniesieniu wiedzy na temat korzyści z uprawiania sportu i na temat Ruchu Olimpijskiego. Czwarty wiąże się z utworzeniem ścieżek rozwoju dla sportowców (Athlete Pathways Development). Zakłada on uruchomienie nowych lig, wspieranie sportowców w ich rozwoju, rozwijanie rodzimych talentów i stworzenie systemu pomocowego dla sportowców po zakończeniu kariery. Element piąty (Sport Management) koncentruje się na wspieraniu funkcjonowania klubów, komitetów sportowych oraz federacji, a także na utworzeniu systemu finansowania i kształcenia ekspertów. Ostatni, szósty obszar (Hosting International Events) zakłada organizowanie dużych imprez sportowych o wymiarze międzynarodowym (Sports, 2011, s. 11).

Podkreśla się, że polityka sportowa państwa, realizowana przez wiele współpracujących ze sobą podmiotów, będzie opierać się na trzech wzajemnie uzupełniających się elementach: edukowaniu społeczeństwa i zachęcania go do prowadzenia aktywnego, sportowego trybu życia; rozwijaniu odpowiedniej i nowoczesnej infrastruktury sportowej; kształceniu talentów sportowych i finansowanie ich rozwoju (Qatar National, 2011, s. 196).

Tabela 2

\section{Regularność aktywności fizycznej kobiet w Katarze} powyżej 15. roku życia (2009)

\begin{tabular}{||l|c||}
\hline \multicolumn{1}{|c|}{ Regularność } & Udzial (\%) \\
\hline Regularnie & 15 \\
\hline Czasem & 36 \\
\hline Rzadko & 32 \\
\hline Nigdy & 17 \\
\hline Ilość respondentów & 959 \\
\hline
\end{tabular}

Źródło: Qatar National Development Strategy 2011-2016. Towards Qatar National Vision 2030, Qatar General Secretariat for Development Planning 2011, s. 196.

Katar stoi na stanowisku, że sport pozwala zbudować nowoczesne, „spójne” (cohesive) społeczeństwo, a także zdrowe - nie tylko fizycznie, ale również zadowolone w wymiarze psychicznym. Politycy tego państwa uważają że sport przynieść może rozwój turystyki, wzmocnić rodzinę i wspólnotę (develop stronger families and strengthen community cohesion), co jednak należy rozpatrywać pamiętając o braku rodzimych tradycji sportowych, przynajmniej w odniesieniu do sportów popularnych na zachodzie (Qatar National, 2011, s. 203). W strategii sektorowej możemy zapoznać się z dokładnym stanowiskiem Katarczyków: „sport i aktywność fizyczna, zarówno dla rekreacji i w przypadku zawodnictwa, ma we wszystkich grupach społecznych ważną rolę. Sport łączy jednostki, rodziny, społeczności i kraje razem dzięki zabawie i uczestnictwu, poprawia dialog i łączy różne kultury. Zaszczepia dyscyplinę, pewność siebie i zdolności przywódcze, promuje takie wartości jak tolerancja, współpraca i szacunek" (Sports, 2011, s. 10). Do pewnego stopnia wydaje się zasadne stwierdzenie, iż za sprawą sportu władza może chcieć zredukować ryzyko niepokoju wśród młodych ludzi, analogicznie do wydarzeń w Afryce Północnej (choć należy mieć na uwadze inną strukturę społeczną i odmienne problemy gospodarcze) - znajdując im zajęcie, cel w życiu, zmniejsza się ryzyko frustracji. 
Sport może pomóc w zlikwidowaniu złych nawyków wśród Katarczyków, którzy mają mało ruchu (co jest zrozumiałe przy takich temperaturach i wysokiej stopie życiowej, pozwalającej korzystać z samochodów). Docelowo zmniejszyć ma się niepokojąco wysoki odsetek osób otyłych, który wśród dorosłych wynosi 32 procent oraz z nadwagą (Qatar National, 2011, s. 196). W tym celu wprowadzono nowy program wychowania fizycznego, który jest obowiązkowy dla dzieci do lat 12. Jak wynika z oficjalnej strategii, sport jest traktowany również jako instrument zwiększania emancypacji kobiet (aktywnych pozostaje 15 procent - zob. tabela 2), a pośrednio popularyzujący wysiłek fizyczny wśród dzieci.

\section{Sport jako instrument polityki zagranicznej}

Poza celami wewnętrznymi, sport odgrywa niezwykle istotną rolę w zakresie polityki zagranicznej. W przypadku Kataru, koncentrującego się na soft power, można postawić tezę, że sport ma przede wszystkim służyć jako narzędzie do działania w wymiarze międzynarodowym i to pomimo, iż wymiar zewnętrzny został praktycznie pominięty w oficjalnych strategiach. W dokumentach rządowych ograniczono się do ogólnikowego stwierdzenia, iż sport „,zwiększa regionalny i międzynarodowy wizerunek kraju” (Qatar National, 2011, s. 196).

W odniesieniu do Kataru, inwestowanie w sport, szczególnie poza granicami kraju, daleko wykracza poza chęć wspierania zdrowego trybu życia. Sport jest traktowany jako niezwykle ważny instrument budowania wizerunku Kataru we współczesnym świecie jako państwa przyjaznego, otwartego i nowoczesnego. Jednym z najważniejszych elementów wzmacniania wizerunku jest inwestowanie na rynkach zagranicznych. Istotnym instrumentem do realizacji tego celu stał się utworzony w 2005 roku przez katarskie ministerstwo finansów i katarski komitet olimpijski Qatar Sport Investment, a także stacja al-Dżazira Sport, która w regionie Bliskiego Wschodu i Afryki Północnej stanowi jednego z liderów na rynku praw do transmisji wydarzeń sportowych, a także coraz aktywniej operuje na rynkach europejskich i w Stanach Zjednoczonych.

Efektywne wykorzystanie Qatar Sport Investment sprawiło, że słynny klub FC Barcelona za sumę 195 milionów dolarów zrezygnował z tradycji i zamieścił na koszulkach logo Qatar Foundation i Qatar Airways. W 2012 roku Qatar Sports Investment wykupił pakiet większościowy we francuskim klubie piłkarskim Paris Saint Germain (rok wcześniej zakupiono sekcję piłki ręcznej), którego katarski prezes - równocześnie dyrektor al-Dżazira Sport, otworzył we Francji dwa kanały sportowe beIN Sport. Dzięki tej transakcji, a także za sprawą spektakularnych i wielomilionowych transferów (Anglik David Beckham, Szwed Zlatan Ibrahimovic, Brazylijczycy Thiago Silva i Lucas, Urugwajczyk Edinson Cavani), o Katarze zaczął mówić cały piłkarski świat. Jak stwierdził Damien Coruzzi, „tak jak świat nauczył się kochać Amerykę za sprawą Marlona Brando i Marylin Monroe, tak samo poznaje Katar dzięki Paris Saint Germain i Davidowi Beckhamowi" (Coruzzi, 2013).

Taka pragmatyczna i celowa polityka pozwala również nawiązać lub wzmocnić relacje polityczne i gospodarcze. Doskonałym przykładem jest wykupienie w 2010 roku występującego w hiszpańskiej Primera Division piłkarskiego klubu Málaga CF. Zwróci- 
ło to uwagę setek tysięcy Hiszpanów na Katar, który inaczej pozostały dla nich miejscem zupełnie nieznanym, anonimowym. Zakup klubu przez członka katarskiej rodziny królewskiej stanowiło element przemyślanej strategii, bowiem w tym samym czasie zaczęto inwestować miliony dolarów w Andaluzji. Wejście w posiadanie zespołu i dofinansowanie narodowej dla Hiszpanów dyscypliny sportowej sprawiło, że katarscy biznesmeni przestali być anonimowi. Stali się wiarygodniejsi. Podobny mechanizm próbowano zastosować we Francji, ale tam pomysł inwestycji socjalnych w biednych dzielnicach spotkał się ze sprzeciwem (Sayare, 2012).

Podobny manewr wykorzystywania sportu do celów promocyjnych, gospodarczych i politycznych Katarczycy zastosowali z powodzeniem we Francji. Wykupienie 70 procent udziałów wielkiego, ale będącego w trudnej sytuacji finansowej, wspomnianego klubu Paris Saint Germain dało Katarczykom możliwość bliskich kontaktów z Nicolasem Sarkozym, który nadal ma we Francji znaczące wpływy polityczne. Nie jest przypadkiem, że były prezydent jest widywany na trybunach z księciem Szajchem Tamimem Hamaded Ibn Chalifą Al Sanim, który został nowym emirem. Wcześniej Sarkozy pilotował otwarcie w Doha francuskiej szkoły (Lycée Voltaire).

Nawiązanie bliskich relacji sportowych, a następnie gospodarczych dało szansę na zbliżenie polityczne, czego emanacją był aktywny udział Kataru w zainicjowanej przez Paryż agresji na Libię (2011), kiedy to emir wydzielił na potrzebę operacji sojuszniczej bojowe odrzutowce Mirage 2000, a także transportowe C-17 Globemaster III (Roberts, 2011). Niejako w nagrodę Katar wstapił do... Międzynarodowej Organizacji Frankofonii (Organisation internationale de la francophonie) $\mathrm{i}$ to $\mathrm{z}$ pominięciem typowego dla wszystkich kandydatów okresu przejściowego (w charakterze „obserwatora”). Wszystkie te działania składają się na przemyślany plan, którego celem jest nie tylko osiagnięcie zysków finansowych, ale związanie się z silniejszymi aktorami stosunków międzynarodowych, co może okazać się niezwykle cenne w razie sytuacji kryzysowej.

Bez wattpienia najważniejszym elementem sportowego soft power w nadchodzących latach będzie organizacja mistrzostw świata w piłce nożnej w 2022 roku, w walce o które pokonano Stany Zjednoczone, Australię, Japonię i Koreę Południową. To sukces trudny do przecenienia, bowiem będzie to pierwszy mundial rozgrywany na obszarze Bliskiego Wschodu. Wybór dyscypliny nie jest przypadkowy - futbol jest bodaj najpopularniejszą dyscypliną sportową na świecie, mającą setki milionów kibiców - niezależnie od regionu świata, kultury i religii. Od początku próba uzyskania prawa do goszczenia największej obok Igrzysk Olimpijskich imprezy sportowej na świecie miała wymiar niemal przede wszystkim marketingowy, polityczny i gospodarczy, a mniej sportowy. O ile bowiem w Polsce, przy okazji Euro 2012, liczono, że tak duża impreza pozwoli popchnąć do przodu rodzimą piłkę nożną, chociażby za sprawą nowoczesnych stadionów, to podejście katarskie jest zupełnie inne. Świadczy o tym fakt, iż stadiony, które powstaną na mundial 2022, zostaną po imprezie rozebrane (Lowe, 2010). Podczas trwania imprezy o Katarze usłyszą setki milionów osób. Dla przykładu, finał w 2010 roku pomiędzy Holandią a Hiszpanią obejrzało około 700 milionów widzów na całym świecie. W przypadku finału 2022 roku z pewnością nie będzie mniej.

Szybko okazało się, że strategia sportowego soft power za pośrednictwem mundialu 2022 stanowi broń obosieczną. Promując konkretny produkt, w tym przypadku państwo jako takie, istnieje ryzyko, że nie wszyscy będą mówić o nim dobrze. Już sama decyzja 
wzbudziła kontrowersje. O bardziej politycznym niż tylko sportowym wymiarze decyzji FIFA świadczy fakt, iż w obliczu klęski amerykańskiego zgłoszenia (przy aktywnym poparciu Billa Clintona) w mało dyplomatyczny sposób głos zabrał prezydent Barack Obama, który stwierdził, iż była to w jego odczuciu ,zła decyzja” (Madison, 2010). Wydarzenie to zostało odczytane przez pryzmat polityki także na Bliskim Wschodzie. Dla przykładu, mieszkający w Doha egipski teolog Jusuf al-Karadawi podczas piątkowej modlitwy stwierdził z zadowoleniem, że wybór Kataru to „to policzek w twarz Stanów Zjednoczonych. To zwycięstwo wobec polityki marginalizacji Bliskiego Wschodu" (Al-Delimi, 2010).

Cień na wybór Kataru kładą również liczne i zrozumiałe zarzuty natury sportowej. Katar to wszak państwo bez jakichkolwiek tradycji piłkarskich. Niewielkie stadiony są na ogół puste. Co więcej, Katar charakteryzuje się cechami niekorzystnymi jak ekstremalnie wysokie temperatury $\mathrm{w}$ okresie letnim, co będzie, jeśli mistrzostwa nie zostaną przeniesione na inną porę roku, problemem nie tylko dla kibiców, ale również sędziów, którzy - jak wynika z przedstawionych UEFA badań Bedfordshire University - przy zbyt wysokiej temperaturze popełniają średnio nawet 25 procent więcej błędnych decyzji (Collins, 2012). Nic więc dziwnego, że krytycznie wypowiedział się również Christian Seifert, prezes niemieckiej Bundesligi, który uznał, że wybór Kataru to decyzja, która „nie bierze pod uwagę sportowej perspektywy”, lecz jest „motywowana politycznie” (Harris, 2013). Do tego dochodzą inne problemy, które mogą wydawać się prozaiczne, ale są istotne z perspektywy kibica. Dotyczy to na przykład alkoholowej prohibicji. Co więcej, Katar jest mały, co w przypadku napływu kilku, a nawet kilkunastu milionów turystów z całego świata może doprowadzić do jego paraliżu.

Co więcej, otwierając się na zewnątrz Katar ujawnia nie zawsze korzystne z własnej perspektywy fakty, które decydenci z emiratu chcieliby ukryć. Problem dla budowy pozytywnego wizerunku zwiększają bowiem dodatkowo dwa elementy. Pierwszy to ujawniony przez wpływowy magazyn „France Football” skandal korupcyjny. Według dziennikarzy Katar milionami dolarów przekupił członków komisji decyzyjnej, zyskując przychylność prezydenta Francji Nicolasa Sarkozy'ego oraz Michela Platiniego - Francuza stojącego na czele UEFA. Michel Zen-Ruffinen, były sekretarz generalny FIFA, wyjawił, że Katarczycy przekupywali afrykańskich członków komitetu wykonawczego w zamian za głosy (Scott, 2011). Chcąc zyskać poparcie Katarczycy wykupili, a dzięki temu ocalili od bankructwa, ulubiony klub piłkarski ówczesnego prezydenta Francji - wspomniany Paris Saint Germain. Smaczku dodaje fakt, że tuż po tym Laurent, syn Michela Platiniego, otrzymał pracę w firmie zarządzanej przez Katarczyków (Conn, 2013). Doszło ponoć nawet do tajnego spotkania w Pałacu Elizejskim pomiędzy Nicolasem Sarkozym, Michelem Platinim oraz przedstawicielem katarskiej rodziny królewskiej (Lichfield, 2013). Chociaż ostatecznie niczego nie udowodniono, to wyraźna rysa na wizerunku pozostała. Trudno bowiem uznać, że Katar został wybrany na gospodarza w uczciwej rywalizacji - tym bardziej w świetle wydarzeń z 2015 roku i otwartych oskarżeń o korupcję w strukturach FIFA, także przy wyborze gospodarzy.

Drugim elementem rzucającym się mocnym cieniem na marketingowe (promocyjne) działania Kataru, utrudniające budowanie pozytywnej marki, jest tak zwany system $k a-$ fala, a więc quasi-feudalnego „,sponsoringu”, na który zwrócili uwagę zachodni dziennikarze i specjaliści (Morin, 2013; Naufal, Genc, 2012, s. 35 i 89). Mechanizm ten ma 
charakter niewolniczy - zmiana pracy przez pracownika (przede wszystkim z państw azjatyckich takich jak Bangladesz, Indie czy Filipiny) jest w praktyce bardzo utrudniona, a prawo do przemieszczania ograniczone. Problemem są również fatalne warunki pracy, brak opieki zdrowotnej, ubezpieczeń, liczne wypadki. Marine Hyde na łamach "The Guardian” zapytała otwarcie: „ile zgonów niewolników jest gotowa znieść FIFA?” (Hyde, 2015).

Tak postawione pytanie to nie tyle publicystyczna retoryka, co rzeczywistość. Po wyborze przez FIFA Kataru w sprawę bezpośrednio zaangażowało się największe światowe zrzeszenie związków zawodowych ITUC (International Trade Union Confederation), skupiające podmioty w 155 państwach świata. Stanowisko tej organizacji nie pozostawia pola do interpretacji. Sekretarz generalny Sharan Burrow wyraziła „zszokowanie” poziomem nadużyć dodając, iż cała Zatoka Perska „znajduje się bez wątpienia na szarym dnie jeśli chodzi o prawa pracownicze. To państwa niewolnicze" (Montague, 2013).

Sekretarz generalny brytyjskiego związku zawodowego Frances O’Grady stwierdziła: „ilość zabitych osób na placach budowy jest w Katarze większa ośmiokrotnie niż w Wielkiej Brytanii i innych krajach rozwiniętych. Piłkarscy fani będą zszokowani, gdy dowiedzą się jak traktuje się [w Katarze] pracowników - warunki przypominają współczesne niewolnictwo" (Unless, 2013). Przy okazji tej sprawy przeciwnicy mundialu w Katarze zaczęli nagłaśniać sprawy grających w Katarze piłkarzy, jak Francuz Zahir Belounis oraz Marokańczyk Abdeslam Ouaddou, których kontrakty nie były respektowane, a pensje niezapłacone.

Mając świadomość tej wizerunkowej katastrofy katarscy decydenci przystapili do działania. W drugiej połowie 2012 roku rozpoczęto rozmowy z ITUC, a także z Human Rights Watch. W walkę o lepsze prawa człowieka włączyła się Qatar Foundation. Zapowiedziano likwidację systemu kafala (Montague, 2013). W 2013 roku zorganizowano turniej piłkarski dla zagranicznych pracowników. Ogłoszono przyjęcie „karty pracowniczej" przez Wysoki Komitet ds. Mundialu (Qatar 2022 Supreme Committee), który zakłada wprowadzenie podstawowych praw - w tym zakazu karania pracowników skarżących się na łamanie ich praw. W ten sposób Katar stara się przekonać świat, że co prawda sytuacja jest zła, ale władze są zdeterminowane, aby było lepiej mając świadomość problemu. Póki co jednak to jedynie działania propagandowe, ponieważ system niewolniczy jest w Katarze nadal utrzymywany.

Taka polityka może jednak prowadzić do poważnych konsekwencji wewnętrznych. Sportowy instrument zmienia katarskie społeczeństwo i panujące w nim zasady. Dotyczy to chociażby liberalizacji w zakresie dostępności alkoholu, promowania w edukacji języka angielskiego kosztem arabskiego. Chcąc zbudować wizerunek państwa nowoczesnego, otwartego i przyjaznego emir - w wyniku presji Międzynarodowego Komitetu Olimpijskiego - zgodził się, aby podczas Igrzysk Olimpijskich w Londynie (2012) wystapily kobiety. Chociaż oddelegowanie kobiet jest z perspektywy europejskiej kultury czymś naturalnym i oczywistym, to z perspektywy Kataru, gdzie dominuje wahhabizm, może być czynnikiem kryzysogennym. $Z$ informacji prasowych wynika, że liberalizacja rodzi niezadowolenie wśród konserwatystów (Dorsey, 2012).

Abstrahując od tego zagrożenia, błyskawiczna reakcja świadczy o kunszcie Katarczyków w zakresie soft power. Nie był to jednak pierwszy przykład pokazujący, że decydenci emiratu potrafią realizować zamierzone cele z wykorzystaniem „miękkich” 
atrybutów siły z niezwykłą skutecznością. Marketingowym sukcesem, również będącym elementem przemyślanej i długofalowej strategii Kataru, było zatrudnienie do budowy pozytywnego wizerunku kraju, by przekonać do wyboru tego państwa jako organizatora mundialu w 2022 roku, Zinedine'a Zidane'a - słynnego piłkarza, który z pochodzenia jest Algierczykiem (co również nie było przypadkowe - w pewnym sensie Zidane reprezentował w ten sposób Bliski Wschód, a więc i Zatokę Perską). Ten jeden z najsłynniejszych piłkarzy na świecie stwierdził: „To najwyższy czas, aby mundial odbył się na Bliskim Wschodzie. Piłka nożna należy do wszystkich. To czas, by organizatorem został Katar" (Lowe, 2010). Trudno określić to inaczej jak PR-owy majstersztyk.

Równie przemyślana przez strategów była druga czesść wypowiedzi zawodnika, który odniósł się do istotnego elementu strategii FIFA, to jest promowania piłki nożnej na świecie. Zidane stwierdził: „Kiedy myślę o tym, czego brakuje młodzieży na Bliskim Wschodzie to jest to wielka impreza jak mistrzostwa świata" (Zidane, 2010). W ten sposób zarzucana słabość Kataru, a więc niewielki odsetek sympatyków piłkarskich i brak tradycji futbolowych, stają się nagle atutem zgodnie z tokiem rozumowania, któremu nie można zarzucić braku logiki - skoro Katar jest futbolową pustynią to przyznanie mu organizacji doprowadzi do popularyzacji dyscypliny, co oznacza otwarcie nowego rynku dającego szanse na gigantyczne zyski. To działanie Kataru idealnie wpisało się w filozofię obecnego sekretarza generalnego FIFA, Seppa Blattera, który promuje rozwój piłki nożnej w regionach, w których brak jeszcze futbolowej kultury i infrastruktury.

\section{Inne elementy sportowego soft power}

Jak zostało już nadmienione, polityka budowania wysokiej pozycji Kataru w systemie międzynarodowym za pośrednictwem instrumentów soft power składa się na długofalową, spójną i przemyślaną strategię. Mistrzostwa świata w 2022 roku będą bez wątpienia wydarzeniem o globalnym rozmiarze, mogącym wynieść świadomość o istnieniu Kataru na zupełnie nowy poziom. Niemniej jednak nawet największa impreza jest wydarzeniem jednorazowym. Pozostaje pytanie - co dalej?

Zdobycie wysokiej pozycji to jedno, a jej utrzymanie to zupełnie inna kategoria wyzwań. Mając tego świadomość, Katar stara się stworzyć takie instrumenty, które będą podtrzymywać ją w kolejnych latach. W przedstawionych w pierwszej części dokumentach rządowych o charakterze strategicznym za istotny cel uznano uzyskiwanie sukcesów sportowych, które również można odczytywać w kategoriach sukcesów politycznych (chociażby jako wyraźnego zademonstrowania istnienia swojego kraju na arenie międzynarodowej i jego siły) (Qatar National, 2011, s. 200). Każde istotne zwycięstwo na dużej imprezie, medal igrzysk olimpijskich, a nawet samo uczestnictwo zapewnia dodatkową promocję. Konkretnych sukcesów jest jednak (póki co?) niewiele. Podczas ośmiu udziałów olimpijskich (1984-2012) zdobyto zaledwie cztery medale - wszystkie brązowe (z czego dwa w Londynie w 2012 roku - zob. tabela 3). Rośnie jednak systematycznie ilość zgłaszanych sportowców - o ile podczas debiutanckiej olimpiady w Los Angeles (1984) katarska drużyna narodowa liczyła 17 sportowców, to w Barcelonie (1992) było już ich 31 (Qatar National, 2011, s. 200). 
Cel, jakim jest zwiększenie ilości sukcesów sportowych pod katarską flagą, decydenci polityczni starają się osiagnąc na trzy sposoby. Pierwszy z nich opiera się na zatrudnianiu uznanych sportowców, głównie piłkarzy, w schyłkowej fazie swej kariery, którzy następnie reprezentują katarskie kluby. Ten kierunek, zapewne głównie z powodu motywacji finansowej, wybrali tak znani piłkarze jak Hiszpan Fernando Hierro (Real Madryt), Holendrzy Frank i Ronald de Boer (Ajax Amsterdam, FC Barcelona), Nigeryjczyk Taribo West (Inter Mediolan, AC Milan), Hiszpan Josep Guardiola (FC Barcelona), Niemiec Stefan Effenberg (Borussia Mönchengladbach, Bayern Monachium, Fiorentina), Francuz Frank Leboeuf (Chelsea, Olimpique Marsylia), Irańczyk Ali Daei (Bayern Monachium, Hertha Berlin), Brazylijczyk Juninho Pernambucano (Vasco da Gama, Olympique Lyon), Francuz Marcel Desailly (AC Milan, Chelsea), Nigeryjczyk Jay-Jay Okocha (Fenerbahçe, Paris Saint Germain, Bolton), Argentyńczyk Gabriel Batistuta (Fiorentina, Roma), Niemiec Mario Basler (Hertha Berlin, Werder Brema, Bayern Monachium, 1.FC Kaiserslautern), Brazylijczyk Romário (PSV, Barcelona, Flamengo), Iworyjczyk Abdul Kader Keïta (Lille, Lyon, Galatasaray), Hiszpanie Raúl (Real Madryt, Schalke 04) i Xavi (FC Barcelona) a z polskich Jacek Bąk (Lyon, Lens) i Euzebiusz Smolarek (Feyenoord Rotterdam, Borussia Dortmund). Przełożyło się to na zwiększenie wiedzy o Katarze w kręgach sympatykach sportu, a także pewne sukcesy katarskich klubów piłkarskich w rozgrywkach azjatyckich - o ile w sezonie 2002/2003 Katar mógł wystawić tylko jedną drużynę do rozgrywek Asian Football Confederation Champions League to obecnie są to cztery. W 2011 roku katarski Al-Sadd S.C. pokonał japoński Jeonbuk Hyundai Motors 4:2 w rzutach karnych (2:2). W składzie Katarczyków wystąpił wspomniany Abdul Nader Keïta, który zdobył bramkę.

Medale olimpijskie Kataru (1992 - 2012)

Tabela 3

\begin{tabular}{|l|c|c|c|c||}
\hline \multicolumn{1}{|c|}{ Imię i nazwisko } & Narodowość & Medal & Olimpiada & Dyscyplina \\
\hline Mohammad Sulejman & Somalia & brązowy & Barcelona $(1992)$ & bieg na $1,5 \mathrm{~km}$ \\
\hline Sajjid Saif Asaad & Bułgaria & brązowy & Sydney $(2000)$ & ciężary $(105 \mathrm{~kg})$ \\
\hline Nasser Al Attijah & Katar & brązowy & Londyn $(2012)$ & strzelectwo \\
\hline Mutaz Essa Barszim & Katar & brązowy & Londyn $(2012)$ & skok wzwyż \\
\hline
\end{tabular}

Źródło: Opracowanie własne.

Niewielka pula własnych talentów sportowych (efekt małej populacji rodzimej i dopiero powstającej infrastruktury sportowej) sprawia, że drugim sposobem Katarczyków jest naturalizacja, przez którą rozumieć należy ,zmianę narodowości, [...] przyznanie obywatelstwa obcokrajowcowi na jego wniosek" (Boczek, 2005, s. 190). Jako przykłady „nowych” Katarczyków podać można zawodników reprezentujących Katar podczas Igrzysk Olimpijskich: Chinki Chen Zhu (szachy), czy też Bułgara Janiego Marczokowa vel Salema Dżabera (ciężary). Jak w 2006 roku pisał portal „NBC Sports”, ,istnieją doniesienia, iż w 1999 roku Katar zapłacił bułgarskiej federacji ciężarowej milion dolarów za ośmiu sportowców [...] Większość z nich niemal od razu otrzymała arabskie imiona [...] Katar przyjął wielu sportowców z Kenii oraz grającego dla Kataru piłkarza z Urugwaju" (Qatar Lures, 2006). To także pierwszy katarski medalista (Barcelona 1992), którym był Somalijczyk Mohammad Sulejman (bieg na 1,5 tysiąca metrów), bułgarski brązowy medalista (Sydney 2000) Bułgar Angel Popow (ciężary), który przybrał imię 
Saif Sajjid Asaad oraz Kenijczyk Saif Sajiid Szahin (bieg przez płotki). Katarska drużyna piłkarska również pełna jest naturalizowanych piłkarzy. Wystarczy wymienić takie osoby jak Mohammad Kasola z Ghany, Ibrahim Madżid z Kuwejtu (z pochodzenia Palestyńczyk, podobnie jak pomocnik Wesam Rizik), czy też Magid Mohamed z Sudanu i Jusef Ahmed z Arabii Saudyjskiej.

Tabela 4

Obiekty sportowe należące do Qatar Olympic Committee oraz Aspire

\begin{tabular}{||l|c|c|}
\hline \multirow{2}{*}{\multicolumn{1}{c|}{ Rodzaj }} & \multicolumn{2}{c|}{ Ilość } \\
\cline { 2 - 3 } & $\mathbf{2 0 0 8}$ & $\mathbf{2 0 1 0}$ \\
\hline Stadiony sportowe & 10 & 12 \\
\hline Boiska piłkarskie & 71 & 90 \\
\hline Baseny & 18 & 18 \\
\hline Hale zadaszone & 32 & 35 \\
\hline Boiska baseballowe & 8 & 9 \\
\hline Boiska do piłki ręcznej & 11 & 12 \\
\hline Boiska do siatkówki & 8 & 11 \\
\hline Tory wyścigów wielbłądów & 0 & 0 \\
\hline Tory wyścigów konnych & 1 & 3 \\
\hline Tory wyścigów samochodowych & 3 & 23 \\
\hline Hale tenisowe & 23 & 20 \\
\hline Hale tenisa stołowego & 20 & 3 \\
\hline Hale hokejowe & 3 & \\
\hline \hline
\end{tabular}

Źródło: Qatar National Development Strategy 2011 2016. Towards Qatar National Vision 2030, Qatar General Secretariat for Development Planning 2011, s. 199.

$\mathrm{Z}$ jednej strony tego rodzaju działania przynoszą wymierne korzyści w postaci medali (głównie na Igrzyskach Azjatyckich), ale z drugiej mają wyraźne wady. Jak zauważa Wladimir Andreff, „o ile z punktu widzenia kraju, który naturalizował sportowca, korzyścią jest zyskanie dobrego zawodnika mogącego reprezentować dany kraj (Katar), to takie działania mogą jednocześnie osłabić lub nawet zneutralizować lokalne działania na rzecz szkolenia talentów. Czasem po prostu drożej jest wyszkolić sportowca niż go kupić" (Andreff, 2012, s. 104).

Katarczycy mają jednak świadomość, że rodzimy gwiazdor ma większą wartość „użytkową” w wymiarze wewnętrznym. Jak możemy przeczytać w Sports Sector Strategy (2011-2016), dokumencie postulującym wprowadzenie w życie spójnych i długofalowych strategii rozwoju, „narodowi bohaterowie sportowi mogą stanowić inspirację dla młodych Katarczyków, by uprawiali sport, wybierali zdrowe i twórcze życie, a także realizowali swoje marzenia" (Sports, 2011, s. 8). Tym samym rozwijanie własnych talentów to trzecia przyjęta metoda, również docelowo pozwalająca skutecznie realizować sportowy soft power. Kluczowe zadanie powierzono dwóm podmiotom: Katarskiemu Komitetowi Olimpijskiemu (Qatar Olympic Committee) oraz powołanemu dekretem emira w styczniu 2008 roku Aspire Zone Foundation. W ramach programu Aspire Football Dreams specjaliści z Kataru przejrzeli profile ponad 3,5 miliona młodych zawodników, z których część otrzymała albo możliwość szlifowania zdolności w akademii w Katarze, albo w filii w Senegalu (Manfred, 2014). Z powodu młodego wieku być może część z nich uda się skutecznie zasymilować, a następnie oprzeć na nich drużynę 
narodową, która pozwoliłaby osiągnąć kolejny cel o niezwykłym potencjale marketingowym - awansować z piłkarską drużyną narodową na mistrzostwa świata. Działania te wspiera zlokalizowany w Aspire Zone pierwszy w Zatoce Perskiej specjalistyczny szpital ortopedyczny i medycyny sportowej ASPETAR. Pierwszy sukces już jest: brązowy medalista z Londynu (2012) Mutaz Essa Barszim to absolwent Aspire Academy.

W celu osiagnięcia zakładanych celów wprowadzono pierwsze programy, chociażby SSDP (Sport Skill Development Programme). Stworzono sportowe stypendia i dotacje. W 2004 roku zainicjowano pierwsze duże projekty infrastrukturalne, które mają dać nowoczesną bazę treningową (choć ta obecnie jest ilościowo imponująca - zob. tabela 4). Zadanie to jest tym bardziej godne podziwu, iż w przypadku Kataru powstaje ona dosłownie na pustyni. W przypadku inwestycji związanych z mistrzostwami świata w 2022 roku Katar zainicjował szacowany na 120 miliardów dolarów program budowy, który zawiera między innymi stworzenie 12 niezwykle nowoczesnych stadionów z systemem chłodzenia, 90 tysięcy dodatkowych miejsc hotelowych, linie metra oraz sieć kolejową.

\section{Podsumowanie}

W przypadku Kataru działania sportowe w wyraźnym stopniu wykraczają poza chęć kultywowania tężyzny fizycznej i promowania zdrowego trybu życia. Sport w emiracie odgrywa rolę istotnego wsparcia polityki państwa - zarówno w wymiarze wewnętrznym, jak i, a właściwie przede wszystkim, zewnętrznym (międzynarodowym). W tym pierwszym istotne cele to chęć przekształcenia konserwatywnego społeczeństwa w nowoczesne i otwarte, zmiana złych nawyków wywołujących choroby, większa emancypacja kobiet oraz chęć zredukowania potencjalnego zagrożenia ze strony młodych Katarczyków, którzy w sporcie znajdą zajęcie, a być może cel życia.

Bez wattpienia dominującym celem katarskiej polityki sportowej jest wspieranie soft power w polityce zagranicznej. O zewnętrznym charakterze celów świadczy najlepiej to, że katarskie władze za priorytet nie uznały inwestowanie w tradycyjne, rodzime sporty (sokolnictwo, wyścigi koni i wielbłądów), lecz w te dyscypliny, które charakteryzuje rodowód zdecydowanie zachodni, a które nie mają tradycyjnego umocowania w regionie. Dotyczy to także piłki nożnej, która nie znajduje w Katarze żadnych tradycji. Innymi słowy, priorytetowe kierunki nie odpowiadają potrzebom społecznym i mają wymiar stricte polityczny, o czym opłacanie przypadkowych osób, aby udawały fanów Kataru (Qatar hires, 2014), dobitnie świadczy.

Wydaje się zasadne uznanie, iż cel, jakim było spopularyzowanie Kataru w świecie, został w ostatnich latach osiagnięty. Do form soft power, które się do tego przyczyniły, zaliczyć można takie działania jak powołanie telewizji al-Dżazira, a wcześniej linii lotniczych Qatar Airways, organizowanie niezliczonych konferencji oraz szczytów. Istotnym elementem były działania o charakterze sportowym - organizowanie dużych imprez sportowych, w tym chociażby XV Igrzysk Azjatyckich, a także agresywne inwestowanie w Europie, chociażby w kluby piłkarskie (Málaga CF oraz Paris Saint Germain).

Działania takie nastawione są obecnie na wzmocnienie pozycji państwa w systemie międzynarodowym, a także utworzenie z Kataru marki kojarzącej się z miejscem stabilnym, otwartym, wartym odwiedzenia i godnym inwestowania. Docelowo, poza 
wzmocnieniem gospodarki, ma to pozwolić na zrealizowanie istotnego celu, jakim jest zwiększenie legitymacji Kataru w systemie międzynarodowym, gdzie - szczególnie w przypadku mikropaństwa - podlegać może ona kwestionowaniu ze strony silniejszych (większych) sąsiadów. Im większa legitymacja Kataru, jego znaczenie w systemie międzynarodowym, tym większe prawdopodobieństwo przetrwania.

Chociaż polityka zagraniczna, nastawiona na agresywne wzmacnianie pozycji międzynarodowej, wskutek niepowodzeń w Egipcie i Syrii zakończyła się - przynajmniej na ten moment - fiaskiem, o czym świadczy zmiana na stanowisku emira, to wydaje się bardzo prawdopodobne, iż w kolejnych latach wykorzystywane soft power poprzez sport będzie kontynuowane - w 2016 roku Katar ma zorganizować mistrzostwa świata w kolarstwie szosowym, a dwa lata później mistrzostwa świata w gimnastyce artystycznej. W 2019 roku na katarskiej ziemi odbyć się mają mistrzostwa świata w lekkoatletyce. W 2024 roku Katar chciałby zorganizować igrzyska olimpijskie.

Tak jak próba zyskania kapitału w wymiarze „klasycznej polityki” zakończyła się niepowodzeniem w wyniku błędnych kalkulacji w Syrii, a szczególnie Egipcie, także i przed sportowym jej elementem stoją poważne wyzwania, które również mogą przynieść niepowodzenia. Bez wątpienia najważniejszym składnikiem opisywanej strategii Kataru jest piłkarski mundial w 2022 roku. Zakończone sukcesem starania o prawo do organizacji tego wydarzenia wpisują się w katarską strategię wzmacniania pozytywnego wizerunku kraju w świecie i stanowią jeden z największych sukcesów w ramach dyplomacji publicznej. Niemniej jednak seria negatywnych i potencjalnie niebezpiecznych dla Kataru czynników, w tym narastająca krytyka za łamanie praw pracowniczych oraz za trudne warunki klimatyczne, a także coraz poważniejsze zarzuty o korupcję (w tym o to, że Katar zapłacił, by uzyskać prawo do organizacji mistrzostw świata), mogą doprowadzić do gigantycznej klęski, a więc odebrania emiratowi mundialu w 2022 roku.

\section{Bibliografia}

Al-Delimi I. (2010), Qatar's World Cup Triumph Victory for Islam: Cleric, „Al Arabiya News” z dnia 6.12.2010 r., http://www.alarabiya.net/articles/2010/12/06/128677.html.

Amara M. (2013), 2006 Qatar Asian Games: A 'Modernization'Project from Above?, w: Sport, Nationalism and Orientalism, red. F. Hong, Routledge, London.

Andreff W. (2012), Sport events, economic impact and regulation, w: Global Sport Marketing. Contemporary Issues and Practice, red. M. Desbordes, A. Richelieu, Routledge, New York.

Ayoub S. (2012), How Qatar Became a Francophone Country, „Al-Akhbar” z dnia 8.11.2012 r., http:// english.al-akhbar.com/node/13464.

Boczek B. A. (2005), International Law. A Dictionary, Scarecrow Press, Lanham.

Brannagan P. M., Gulianotti R. (2014), Qatar, Global Sport, and the 2022 FIFA World Cup, w: Leveraging Legacies from Sports Mega-Events: Concepts and Cases, red. J. Grix, Palgrave Macmillan, London-New York.

Collins N. (2012), Referees make more mistakes in extreme heat (Bring on Qatar), "The Telegraph" z dnia 18.05.2012 r., http://www.telegraph.co.uk/news/science/science-news/9273290/Refereesmake-more-mistakes-in-extreme-heat-Bring-on-Qatar.html.

Conn D. (2013), Michel Platini: 'All the decisions I make are for the good of football', "The Guardian" z dnia 24.05.2013 r. http:/www.theguardian.com/football/2013/may/24/michel-platini-uefafootball. 
Coruzzi D. (2013), Qatar: Football as Soft Power, „Columbia Political Review” z dnia 16.02.2013 r., http://cpreview.org/2013/02/qatar-football-as-soft-power.

Dorsey J. M. (2012), Soccer meets politics at Doha's Mohammed Abdul Wahhab Mosque, „Middle East Online" z dnia 21.04.2012 r., http://www.middle-east-online.com/english/?id=51830.

Harris R. (2013), Head of Bundesliga slams FIFA's 'politically driven' decision to award Qatar the 2022 World Cup, ,Fox Sports” z dnia 23.05.2013 r., http://www.foxsports.com.au/football/head-of-bundesliga-slams-fifas-politcally-driven-decision-to-award-qatar-the-2022-world-cup/ story-e6frf423-1226648849468.

Hoye R., Nicholson M., Houlihan B. (2010), Sport and Politics. Issues and Analysis, Oxford University Press, Oxford.

Hyde M. (2015), How many slave deaths for the Qatar World Cup can Fifa put up with?, „The Guardian" z dnia 20.05.2015 r., http://www.theguardian.com/football/blog/2015/may/20/slave-deaths-qatar-world-cup-2022-fifa.

Lichfield J. (2013), Nicolas Sarkozy 'colluded'to get Qatar 2022 World Cup, „,The Independent” z dnia 29.01.2013 r., http://www.independent.co.uk/news/world/europe/nicolas-sarkozy-colluded-toget-qatar-2022-world-cup-8471758.html.

Lowe S. (2010), Zidane energizes Qatar's 2022 bid, ,Sports Illustrated” z dnia 25.09.2010 r., http:// www.si.com/more-sports/2010/09/25/qatar-2022.

Madison L. (2010), Qatar to Host World Cup Over U.S. is “Wrong Decision” Obama Says, „CBS News" z dnia 2.12.2010 r., http://www.cbsnews.com/news/qatar-to-host-world-cup-over-us-iswrong-decision-obama-says.

Manfred T. (2014), Why Qatar Has Scouted 3.5 Million Young Soccer Players Around The World, „Business Insider" z dnia 15.07.2014 r., http://www.businessinsider.com/qatar-aspire-academyworld-cup-2014-7.

Montague J. (2013), Desert heat: World Cup hosts Qatar face scrutiny over 'slavery' accusations, „CNN" z dnia 1.5.2013 r., http://edition.cnn.com/2013/04/30/sport/football/football-qatarworld-cup-2022-worker-rights.

Morin R. (2013), Indentured Servitude in the Persian Gulf, „The New York Times - Sunday Review” z dnia 12.04.2013 r., http://www.nytimes.com/2013/04/14/sunday-review/indentured-servitude-in-the-persian-gulf.html.

Naufal G., Genc I. (2012), Expats and the Labor Force: The Story of the Gulf Cooperation Council Countries, Palgrave, New York.

Nye J. S. (2004), Soft Power. The Means to Success in World Politics, Routledge, New York.

Scott M. (2011), Millions paid in bribes for Qatar's 2022 World Cup votes, report claims, ,The Guardian" z dnia 10.05.2011 r., http://www.theguardian.com/football/2011/may/10/millions-bribesqatar-2022-world-cup-claims.

Peterson J. E. (2009), Katar i świat. Budowanie marki mikropaństwa, w: Państwo Katar. Gospodarka - polityka - kultura, red. K. Górak-Sosnowska, R. Czulda, Łódź.

Qatar hires migrant workers as 'fake sports fans' to fill up empty arenas, „The Guardian” z dnia 17.12.2014 r., http://www.theguardian.com/sport/2014/dec/17/qatar-migrant-workers-fakesports-fans.

Qatar Lures Athletes with Citizenship, Cash, „NBC Sports” z dnia 8.12.2006 r., http://www.nbcsports. com/qatar-lures-athletes-with-citizenship.

Qatar megaprojects by 2020 worth $\$ 120$ b, „Saudi Gazette” z dnia 19.02.2013 r., http://www.saudigazette.com.sa/index.cfm?method=home.regcon\&contentid=20130219153721.

Qatar National Development Strategy 2011-2016. Towards Qatar National Vision 2030 (2011), Qatar General Secretariat for Development Planning.

Roberts D. (2011), Behind Qatar's Intervention In Libya, ,Foreign Affairs” z dnia 28.09.2011 r., https:// www.foreignaffairs.com/articles/libya/2011-09-28/behind-qatars-intervention-libya. 
Sayare S. (2012), Qatar is Becoming a Player in French Sport, „The New York Times” z dnia 26.10.2012 r., http://www.nytimes.com/2012/10/27/sports/soccer/with-paris-saint-germainqatar-is-a-player-in-french-sports.html.

Sports Sector Strategy (2011-2016) (2011), Qatar Olympic Committee, Doha.

Unless Qatar improves its treatment of workers, the World Cup vote must be re-run, unions tell UEFA Congress, „Re-Run the Vote: No World Cup Without Workers' Rights” z dnia 23.05.2013, http://www.rerunthevote.org/Unless-Qatar-improves-its?lang=en.

Whitelegg D. (2000), Going for Gold: Atlanta's Bid for Fame, „International Journal for Urban and Regional Research", vol. 24, Issue 4.

Zidane backs Qatar 2022 bid, „Al Jazeera” z dnia 17.09.2010 r., http://www.aljazeera.com/sport/2010 /09/201091714342618127.html.

\section{Sport as an Element of Qatar's Soft Power}

\section{Summary}

Until recently, the State of Qatar remained little recognized throughout the world. However, as a result of a well-considered and long-term brand building strategy, linked closely to foreign and security policy, Qatar has become not only a globally recognized country, but also - due to the disproportion between its geographical size and its impact on international activities - a trustworthy brand that is known and respected in the most important political and business circles. The main goal of this paper is to analyze one of the elements of Qatar's brand building strategy, which is the use of sport for political purposes, and to answer the question as to what degree sport in the analyzed case can help with accomplishing those strategic objectives. To do so, the paper will analyze both the internal and external (international) dimensions of Qatar's sports policy.

Key words: Qatar's foreign policy, soft power, sport, brand building 